\title{
Explicating Literacy Activities at Work: The use of 'okay' as an effective topic-changing device in service request calls
}

\author{
ANN KELLY
}

\begin{abstract}
There is evidence from different spheres that the grounding of understandings of literacy within social practices has gradually become accepted within the adult literacy field in Australia. However, what has not been sufficiently considered are those tacit literacies that underpin such practices in both everyday and work settings. This has been the case particularly for those literacies that are deployed through an oral communication mode in workplaces. This article offers a way of explicating such literacies by showing how the analysis of an audio-recording of a particular occupational activity, namely the reporting of a service request, can render visible particular key literacy features. In this case, such an analysis shows how the marker 'okay' is used in a critical way to close off segments of an interaction and to mark verbally that agreement about a particular aspect of the request has been reached. It is argued that the use of recordings, both audio and video, for the purpose of highlighting tacit competencies has implications not only for adult literacy teachers but for trainers, assessors and curriculum developers within the broader vocational education and training sector.
\end{abstract}

\section{Key socio-cultural influences on conceptions of adult literacy in Australia}

The position that literacy is not restricted to a set of individual's attributes but is grounded in social activities has gradually become accepted within the research, policy and practice literature in the field of adult literacy. Support for such a stance can be traced to the seminal theoretical work of Street (1984), Gee (1995) and Barton, Ivanič and Hamilton (1999), ethnographic studies of literacy practices, policy initiatives and teachers' reflections, especially those focusing on pedagogy in workplace settings. In particular, the situating of 'autonomous' forms of literacy within broader 'ideological' forms by Street $(1984,1993)$ has been crucial in critiquing narrow notions of literacy as decontextualised and individualised and appreciating that all literacy is ultimately ideological. Similarly, Gee's (1996) contention that small 'd' discourses (including literacy discourses) are always located within broader (large 'D') Discourses encompassing 'conventionalised ways of being in the world, or forms of life which integrate words, acts, values, 
beliefs, attitudes, and social identities, as well as gestures, glances, body positions, and clothes' (p. 127) have helped to promote notions that literacy is always contextual. One of Barton, Ivanič and Hamilton's (1999) major contribution was to situate literacy within a social practices model, commonly referred to as 'the new literacy studies framework', which is underpinned by a number of key propositions. These are that literacy must be understood as a set of social practices, 'multiple, patterned by power relationships, purposeful, historically situated and changing over time' (p. 2). It follows, then, that, in all literacy practices, even in the delivery of programs that are ostensibly generic and delivered in formal educational settings, there is an inherent valuing of certain ideas, identities and ways of behaving over others that is being enacted (Street and Street 1991).

An attempt to situate literacy training within a social framework has also been evident within Australian policy, on the basis that it is more effective. For example, a concerted effort was made by the Australian Government in the 1990s to integrate literacy (along with language and numeracy) into vocational education. Initially, this was manifested in the incorporation of literacy into competency statements (Courtenay and Mawer 1996) and then into the delivery of competency-based training through as 'Built In: Not Bolted On' (Bradley, Parker, Perisce and Thatcher 1998). As the phrase implies, the emphasis was placed on integrating literacy into vocational training, rather than separating it out from mainstream vocational provision. A further national initiative was the provision of funds to the Adult Literacy and Numeracy Australian Research Consortium to research how language, literacy and numeracy were being included in the delivery of courses based on training packages. Publications such as those by Kelly and Searle (2001), Sanguinetti (2001), and Trenerry (2001) showed that, while there were some industry trainers who were integrating language, literacy and numeracy into their vocational courses, others continued to perceive these competencies as 'bolted on' and unrelated to their own responsibilities.

From an international perspective, ethnographic studies, such as that undertaken by Gowen (2001) in a hospital, show how important it is to understand literate practices as being embedded within particular social orders. In her study, Gowen showed, among other findings, that the interpretations of workers' literate behaviours by managers did not reflect the actual abilities of their employees. Rather, workers learned when it was politic, or in their occupational or social interests, to adopt, ignore or sabotage particular literacy practices that were prescribed by hospital managers. A training approach based only on individual cognitive development would obviously not consider such factors. Kleifgen (2005) also found that workers had endogenous ways of 'consenting to, coping with, and contesting' (p. 467) the authorised requirements for implementing the quality assurance program ISO 9002 in a small circuit board manufacturing plant in 
California, activities that would also not be appreciated without such close observations of actual worker practices. A further example is available in South African studies (Prinsloo and Breier 1996) which pointed out the importance of mediators in the accomplishment of literate activities, regardless of the acquired literate ability of the participants. Thus, literacy ethnographers such as Gowen, Kleifgen, and Prinsloo and Breier have helped to promulgate notions of a social, as well as a cognitive basis for literacy teaching. This has important ramifications for the work of literacy teachers, policy makers and researchers in the field

A final example of the differing but important influences on the development of social as well as cognitive approaches to literacy teaching is available in the reflections of teachers. As early as the mid-1980s, there was evidence that teachers in Adult Migrant Education Programs recognised that 'autonomous' basic skills literacy programs were not appropriate responses to workers' literacy needs (Campbell, Foley and Mortensen nd). One widespread response to this perception was the use of authentic workplace texts. Through the employment of a systemic functional linguistic approach (eg Prince 1992, Wignell and Boyd 1994), workers were shown how these were constructed to produce particular meanings through the use of both generic features and clausal devices. Since that time, a more 'ideological' approach to literacy training has been promoted through the funding initiatives of the Australian government in the form of the Workplace English Language and Literacy (WELL) program (2009). This involves industry and registered training organisation staff working collaboratively to develop programs that are both pedagogically sound and responsive to workplace needs.

While our understandings about social literacies, particularly those engaged in at work, have been expanded through the promulgation of theories, policies and practices, our knowledge of literacies at work remains scant. This is particularly the case for tacit literacies that are difficult to articulate (for example, those enacted through oral communication modes). The example that is analysed in the next section represents one way of extending knowledge about literacy in situ that has implications for theorists, policy makers and practitioners with an interest in adult literacy. It is based on a transcript of an interaction between an administrative trainee, employed in a local Council office to record service requests made via the telephone, and a primary school staff member who is reporting a problem with a Council sign.

A key feature of the call is the use of the marker 'okay' that is used by the trainee, and in some cases, both parties to acknowledge an understanding has been reached and, by the trainee, as a device to move from one topic to another. It is the topic-changing function that is the focus of my analysis here. It will be argued that, while this marker performs valuable work in moving the call forward, this is not recognised in the documented Business Services 
standards (National Training Information Services nd) that ostensibly capture such work. Initial attempts to document such minutiae as individual competencies, for example, in the metals industries (Towards a New Metal and Engineering Industry Award 1988), have been recognised as not viable., However, I argue in this article that the device 'okay' performs such a pivotal function in the negotiating and reporting work undertaken in the request interactions that were recorded that it should be acknowledged in competency standards. This example is just one such important feature evident across my corpuses of local government activities that have not been incorporated into those units of competency which have been designed to reflect actual work practices. In the final section of this article, a case is made for using audio and video recordings to make such features of everyday practices visible and thus available for recognition.

\section{Recording service requests in a local Council office}

As with any activity, the recording of telephone service requests comprised a number of stages. Figure 1 represents the stages involved in actioning these requests by the Bayside City Council when the data for my study were collected. The first stage involved the focal trainee and service requestors. In the call that is used as an example in this article, a school administration assistant requested attention to a Council mobile library sign located near her school. The transcript shows in fine detail how the two parties verbally assembled the nature of the problem and then followed this with a discussion of its location and level of seriousness. At several points in the interaction the trainee committed the Council to a response that was later formalised through the medium of a service request form. During the call the trainee took notes, the type of information recorded being influenced by the categories that featured on the Council's Customer Service Request form. The electronic completion of this form, usually undertaken some hours following the request, is represented as Stage 2 in the sequence shown in Figure 1. This article centres on Stages 1 and 2. 


\begin{tabular}{|c|c|c|c|c|c|c|}
\hline Stage 1 & & Stage 2 & & Stage 3 & & Stage 4 \\
\hline $\begin{array}{l}\text { Constitution of } \\
\text { the service } \\
\text { request by both } \\
\text { call-taker and } \\
\text { caller \& its } \\
\text { documentation } \\
\text { as notes by } \\
\text { caller }\end{array}$ & $\Rightarrow$ & $\begin{array}{l}\text { Documentation } \\
\text { of the problem } \\
\text { on Customer } \\
\text { Service Request } \\
\text { form } \\
\text { by call-taker }\end{array}$ & $\Rightarrow$ & $\begin{array}{l}\text { Actioning of } \\
\text { response to the } \\
\text { problem and } \\
\text { documentation } \\
\text { of this action by } \\
\text { designated } \\
\text { officer }\end{array}$ & $\Rightarrow$ & $\begin{array}{l}\text { Establishment of } \\
\text { satisfaction with } \\
\text { the resolution to } \\
\text { the problem by } \\
\text { call-taker \& } \\
\text { caller }\end{array}$ \\
\hline
\end{tabular}

Figure1: Stages in responding to a telephone service request within the Bayside City Council

\section{An example of a service request call}

The specific topic of the transcript that is examined in this article was a problem with two posts that were the structural supports for a mobile library sign. The initial phase of this call is not available for consideration here as it occurred prior to approval being granted for the call to be recorded. The abbreviations ' $\mathrm{C}$ ' and ' $\mathrm{T}$ ' refer to the caller and the trainee, respectively".

In this interaction an initial categorisation of the content of the call results in six components, namely, topicalising the problem, warranting the call, locating the source of the problem, establishing caller details, initial actioning of the complaint and closing the call. These components were common across all the calls in my corpus.

It has been noted that lists of components such as this one show 'ideal' organisational structures of activities (eg Drew and Heritage 1992:44).

However, they are of limited use because they do not capture the finer details inherent in accomplishing service requests sequentially in response to local contingencies. In examining such details, topic changing devices have been found to be critical. 


\section{Topic changing devices}

Topic changing devices are common tools used to effect oral communication work. For example, West and Garcia (1988) claim that 'topical talk is as much about how speakers introduce, develop and shift between potential "mentionables" as it is a product of what they actually said" [italics in original] (p. 551). Specifically, such devices can contingently limit what is mentioned at particular points in an interaction. Other conversation analysts (eg Button 1987, 1991, Button and Casey 1984, Maynard 1980) have also noted the importance of topic changing devices in effecting both organisational and mundane conversational work. Topic changing devices can take a variety of forms but what is noticeable in this call is the trainee's use of the marker 'okay' to introduce and shut down components of the call.

Beach (1993) has examined a large corpus of data showing multiple instances of the use of 'okay'. He claims that:

'okay' is employed pivotally, in the midst of, yet at precise

moments of, transition by recipients and current speakers alike, across a variety of speech exchange systems ..., not just in any

sequential environment but where what is 'at stake' involves movements from prior to next-positioned matter(s) (p. 326).

Instances of such work by the marker 'okay' are observable at three points in Transcript 1. First, the trainee uses 'okay' in line 10 to close down the initial description of the problem by the caller and move to the elicitation of information regarding the location of the problem. Similarly, in line 17 the employment of 'okay' by the trainee acts as a 'pivot' to move from locational information to the name of the caller and in line 49 from warranting work to the confirming of action to be taken. This marker, however, achieves additional functions in this call. In lines 25, 35, 46 and 52 both the trainee and the caller appear to use it to indicate an acceptance of the statements by the other and as a device for the closure of a particular focus.

A number of authors analysing talk in institutional settings, particularly those of courtrooms (Atkinson and Drew 1979, Drew 1990) and interview studios (Greatbatch 1986, 1988), have observed that prosecutors and interviewers also change topics relatively abruptly. A contributing factor to this practice in the Council office situation may be the existence of an economic imperative placed on the trainee to gather pertinent information quickly. In this local Council setting the service request forms that were the outcome of each call were dated and were designed in a way that allowed for the insertion of particular information. This information included the nature of the problem, its location and level of seriousness and caller particulars. This level of detail may not have resulted if the talk were allowed to develop without such a constraint. 
Whalen (1995) noted that, in ensuring that critical details such as the location of the problem are entered into dispatch packages, disjunctions in the topicality of the talk may occur as relevant details are sought for the purposes of form completion. It is evident, though, in the interactions that I recorded between the service requesters and the trainee, that this transitional work was undertaken in a way which included the deployment of this marker in a pivotal manner that did not appear to disrupt the flow of talk between the participants of the call.

\section{The role of 'okay' in mediating talk and text in initially recording service requests}

In Figure 2 below, asterisks have been inserted into the text the trainee produced during the service request call to show how and where the marker 'okay'was used, predominantly by the trainee, in the first half of the call to manage the acquisition of required information about the problem that was the source of the call. In addition, arrows show the linkages that developed between the recorded components of the call. Finally, a column of numbers reflects the lines in the transcript where this action occurred.

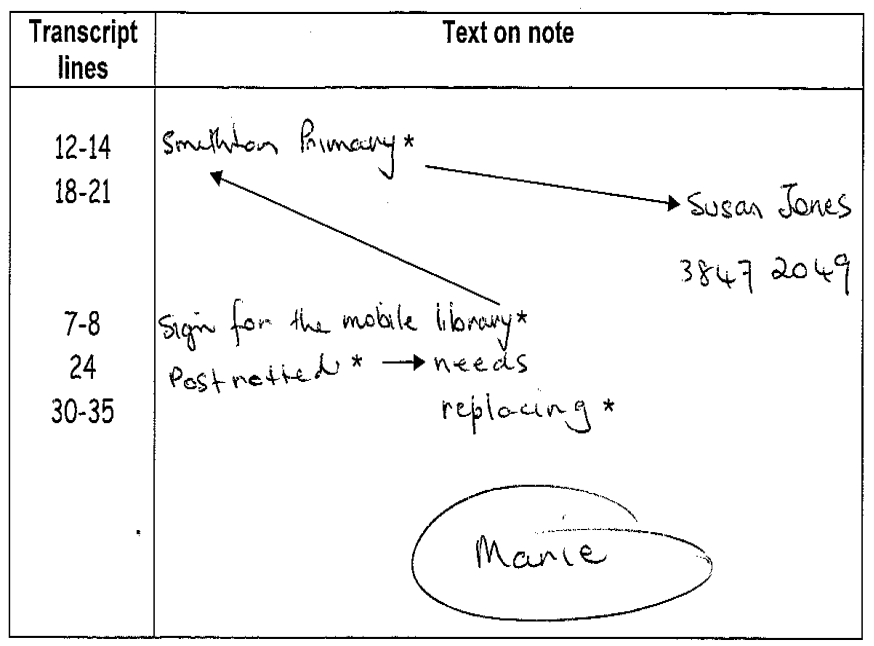

Figure 2: Trainee's note of the call

*denotes the use of marker okay as a topic-changing device

An examination of the content of the note reveals that the key details required to address the problem (Stage 3 in the process represented in Figure 1), namely its nature, location, and a warrant for the call, were documented. In addition, a record was made of the name of the caller and her contact phone number (for follow-up in Stage 4). Further, although there is no videorecording to support the claim, it might be assumed that these details were 
garnered by line 35 of the call. The remaining interaction focuses on determining the seriousness of the problem.

In examining the asterisks in Figure 2, it is evident that the marker 'okay' played an important role in organising the call to meet the organisational requirements of the Council. What is also noticeable is how the layout of the note recording the content of the call on the note did not match its sequential enactment but did match the layout of the Council form developed later.

If we now turn to an examination of the accredited competency standards relating to the processing of complaints (or, in this case, service requests) by which this trainee was assessed, it is clear there is no recognition of the use of topic changing devices to manage the organisational recording requirements of such calls.

\section{Literacies in the element of competency: Process customer complaint}

\begin{tabular}{|c|l|c|}
\hline $\begin{array}{c}\text { Element } \\
\text { complaints }\end{array}$ & $\begin{array}{l}1.1 \quad \text { Performance criteria } \\
\text { communication in accordance with organisational procedures } \\
\text { established under organisational policies, legislation or codes of } \\
\text { practice. } \\
1.2 \text { Obtain, document and review necessary reports relating to } \\
\text { customer complaints. } \\
1.3 \text { Make decisions about customer complaints, taking into account } \\
\text { applicable legislation, organisational policies and codes. } \\
1.4 \text { Negotiate resolution of the complaint and obtain agreement where } \\
\text { possible. } \\
1.5 \text { Maintain a register of complaints/disputes. } \\
1.6 \text { Inform customer of the outcome of the investigation. }\end{array}$ \\
\hline
\end{tabular}

Table 1: BSBCMM301A: Process customer complaints (National Training Information Services, nd, np )

What is clear, however, is the broad nature of the competencies and their linearity. An examination of the transcript and an understanding of the processes employed by the Council in addressing complaints show that, in responding to the calls, the trainee showed she could 'process customer complaints using effective communication in accordance with organisational procedures', '... document and review necessary reports relating to customer complaints', 'make decisions about customer complaints, taking into account applicable ... organisational policies', 'negotiate resolution of 
the complaint and obtain agreement' up to a point and 'maintain a register of complaints' (through the use of a file number on the official form). The final criterion was also likely to be addressed, as it is a key component in the process of attending to requests (Stage 4).

Thus, it might be argued this list captures in a very global manner the key features of the task of recording complaints. However, while I concede that sets of steps such as these might have some initial value, unless they are supported by examples of actual practice, they leave the learners and trainers with little guidance with respect to how the separate components of the activities might be accomplished in a competent manner. For example, with respect to the focus of this article, there is no recognition that the smooth movement from one set of topics to another is important.

\section{Implications for literacy and vocational practices}

The use of the marker 'okay' is just one aspect of how this trainee enacted the moment-by-moment contingencies of service request calls. Other features were noted in the larger doctoral study from which this article derives. However, additional investigations of the actual practices of workers as they are undertaken, using an ethnomethodologically-based approach, such as the one adopted in this study, are needed. Such approaches are important because they explicate the ordered and moral ways in which work activities are accomplished. In particular, the analyses of audio- and videorecordings make explicit the tacit knowledges and skills that are not recognised and thus cannot be articulated.

While additional ethnomethodological and ethnographic studies are needed, they will never be enough. As concluded in my study of the work of thirty administrative trainees (Kelly and Foley, 1999), and evidenced by the sheer numbers of such workers ${ }^{\mathrm{ii}}$, the scope of administrative work and, no doubt, other occupational areas, is wide. Responses to such diversity have been to develop specialities within competency frameworks ${ }^{\text {iv }}$, to allow for a measure of customisation of the content of competencies and to identify acceptance variables within a somewhat limited range. However, a continuing and more pressing problem is the lack of power at the local level to determine the competency statements themselves. Currently, it is standards developers with assistance from stakeholders who engage in this task. The problem with this arrangement is that the voices of the workers who actually accomplish activities, on which competency statements are ostensibly based, are silenced. On the other hand, it is recognised that the opening up of local sources of input for such statements may result in an unmanageable and undifferentiated number of knowledge types and skills.

In promoting an 'ideological' view of literacy, Street (1996) has noted that there may be a problem in the relativism that would result. However, he 
argues that to impose from outside 'fixed, universal and given' genres and forms of literacy is also not the answer. What is needed is a middle path with work for roles for researchers, line supervisors, trainers, standards developers and others in effecting this work for researchers, line supervisors, trainers, standards developers and workers actually engaged in activities to document actual competencies, while simultaneously developing features that are common.

\section{References}

Atkinson John Maxwell and Drew Paul (1979) Order in court: The organization of verbal interaction in judicial settings, Macmillan, London.

Barton, David, Ivanič, Roz and Hamilton, Mary (1999) Introduction in Barton, David, Ivanič, Roz and Hamilton, Mary (eds), Situated literacies: Reading and writing in context, Routledge, London, pp. 1-6.

Beach, Wayne A (1993) Transitional regularities for 'casual' 'Okay' usages. Journal of Pragmatics, vol. 19, pp. 325-352.

Bradley, Sharon, Parker, Penny, Perisce, Sue and Thatcher, Judy (1998) Built In Not Bolted On: An information kit for literacy \& numeracy practitioners, training managers and industry training about language, literacy \& numeracy issues in the delivery of training packages, Department of Employment, Commonwealth of Australia, Canberra, ACT.

Button, Graham (1987) Moving out of closings in Button, Graham Lee, John R E, (eds), Talk and Social Organisation, Multilingual Matters, Clevedon, PA .

Button, Graham (1991) Conversation-in-a-series, in Boden, Deirdre and Zimmerman, Don H, (eds), Talk and Social Structure: Studies in ethnomethodology and conversation analysis Polity Press, Oxford, pp. 251-177.

Button, Graham and Casey, Neil (1984) Generating topic: the use of topic initial elicitors. In Atkinson, Don H and Heritage, J, (eds), Structures of Social Action: studies in conversation analysis, Cambridge University Press, Cambridge, pp. 167-190.

Campbell, Gordon, Foley, Patrick and Mortensen, Wayne (nd) Literacy training: Best practice in Australian industry. Unpublished manuscript.

Courtenay, Marianne and Mawer, Giselle (1995) Integrating English Language, Literacy and Numeracy into Vocational Education and Training, Department of Employment and Training, Canberra, ACT. 
Drew, Paul (1990) Strategies in the contest between lawyer and witness in cross-examination, in Levi, Judith $\mathrm{N}$ and Walke, Anne G, (eds), Language in the Judicial Process, Plenum, New York, pp. 470-520.

Drew Paul and Heritage John (1992) Analysing talk at work: an introduction, in Paul Drew and John Heritage, John, (eds), Talk at Work:

Interaction in Institutional Settings Cambridge University Press, Cambridge, pp. 3-65.

Gee James Paul (1996) Social Linguistics and Literacies: Ideologies in discourse. ( $2^{\text {nd }}$ ed.), Falmer, London.

Greatbatch David L (1986) Aspects of topical organization in news interviews: The use of agenda-shifting procedures by interviewees. Media, Culture and Society, Vol. 8, pp. 441-455.

Greatbatch David L (1988). A turn-taking system for British news interview. Language in Society, vol. 17, no. 3, pp. 401-440.

Gowen, Sheryl, G (2001) The nature and uses of text in the workplace: A cross-case comparison, in Freebody, Peter, Muspratt Sandy and Dwyer, Bronwyn, (eds), Difference, Silence and Textual Practice, Hampton Press, Creskill, NJ, pp 323-336.

Kell, Catherine (1998) Living with the literacy line, Literacy \& Numeracy Studies, vol. 8, no. 2, pp. 79-89.

Kelly, Ann and Foley, Helen (1998) Taking Training to Tasks: The literacy competencies inherent in the tasks of level 3 office administration trainees. Unpublished report.

Kelly, Ann and Searle, Jean (2000) Literacy and Numeracy on the Motorway: A case study of the effects of the inclusion of literacy and numeracy competencies within the civil construction industry training package, Language Australia: Melbourne.

Kleifgen, Jo Anne (2005) ISO 9002 as literacy practice: Coping with quality control documents in a high-technology company, Reading Research Quarterly, vol. 40, no. 4, pp. 450-468.

Maynard, Don W (1980), Placement of topic changes in conversation, Semiotica, vol. 30, pp. 263-90.

National Centre for Vocational Education Research (September quarter, 2009) Australian Vocational Education and Training Statistics: Apprentices and Training - March 2008 retrieved 1 April 2010 from http://www.ncver.edu.au/statistics/aats/quarter/sept2009/aats_septqtr09. pdf

National Training Information Services (nd) BSB07 Table of Contents retrieved 1April 2010 from 
http://www.ntis.gov.au/Default.aspx?/trainingpackage/BSB07/unit/BSB CMM301A

Prince, Dianne (1992) Literacy in the Workplace: A self-study guide for teachers, NSW Adult Migrant English services and Department of Industrial Relations, Employment, Training and Further Education, Surry Hills, NSW.

Prinsloo, Mastin and Breier, Mignonne, (eds) (1996) The Social Uses of Literacy: Theory and practice in contemporary South Africa, Sached Books and John Benjamins Publishing Company, Johannesburg.

Psathas George (1995) Conversation Analysis: The study of talk-ininteraction. Sage, Thousand Oaks.

Psathas, George (1999) Studying the organisation in action: Membership categorization and interaction analysis, Human Studies, vol. 22, pp. 139-162.

Sanguinetti, Jill (2000). The Literacy Factor: Adding value to training: investigation of the inclusion of literacy in training packages in the food processing industry, Language Australia, Melbourne.

Street, Brian V (1984) Literacy in Theory and Practice, Cambridge University Press, Cambridge, MA.

Street, Brian V (ed) (1993) Cross-cultural Approaches to Literacy, Cambridge University Press, Cambridge, MA.

Street, Brian (1996) Preface, in Prinsloo, Mastin and Breier, Mignonne, (eds), The Social Uses of Literacy: Theory and practice in contemporary South Africa, Sached Books and John Benjamins Publishing Company, Johannesburg, pp. 1-9.

Street, Brian V and Street, J (1991) The schooling of literacy in Barton, David and Ivanic, Roz, (eds), Writing in the Community, Sage, London,

Towards a New Metal and Engineering Industry Award: Report of the DIR, MTFU and MTIA mission to UK, Sweden and West Germany (1988). Unpublished report.

Trenerry, Ruth (2000). Investigating Literacy, Language and Numeracy in Training Packages, Language Australia: Melbourne.

West, Candace, and Garcia, Angela (1988) Conversational shift work: a study of topic transition between women and men. Social Problems, vol. 35, pp. 551-75.

Whalen, Jack (1995) A technology of order production: Computer-aided dispatch in public safety communications, in ten Have, Paul and Psathas, George, (eds), Situated Order: Studies in the social organization of talk and embedded activities, International Institute for 
Ethnomethodology and Conversation Analysis and University Press of America, Washington, DC, pp. 186-230.

Wignell, Peter and Boyd, Kate (1994) Kakadu National Park as a Case Study in Workplace Literacy, National Languages and Literacy Institute of Australia, Deakin, ACT.

WELL Workplace English Language and Literacy (WELL) program Overview (2009) retrieved 1 April 2010 from

http://www.dest.gov.au/sectors/training_skills/programmes_funding/pro gramme_categories/special_needs_disadvantage/well/Workplace

Zimmerman Don H (1992) Achieving context: Openings in emergency calls in Graham Watson and Robert M Seiler (eds), Texts in Context: Contributions to ethno-methodology. Newbury Park, London. pp. 3551. London: Newbury Park. 


\section{Transcript 1 (Transcal 1: 09-09-99)}

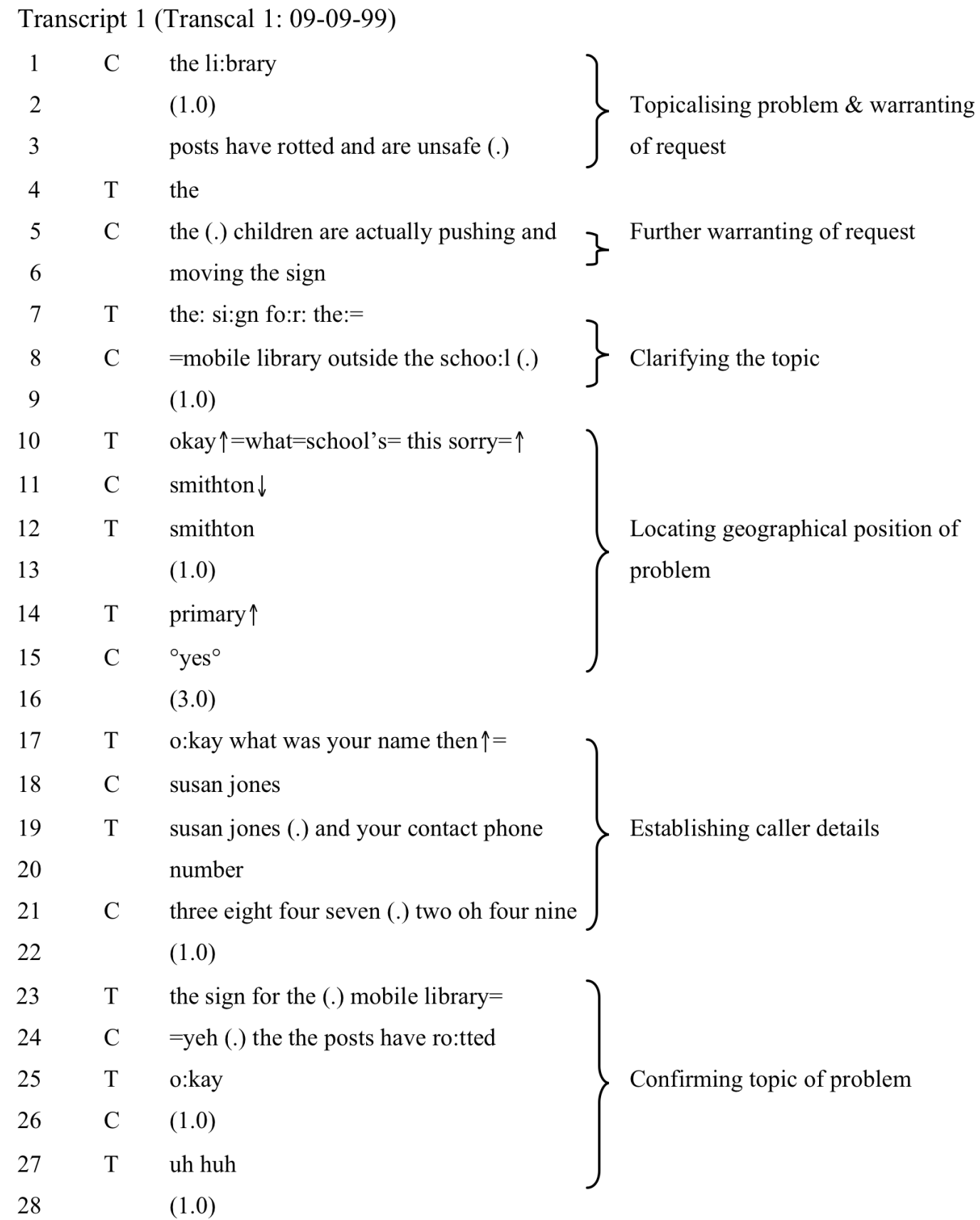




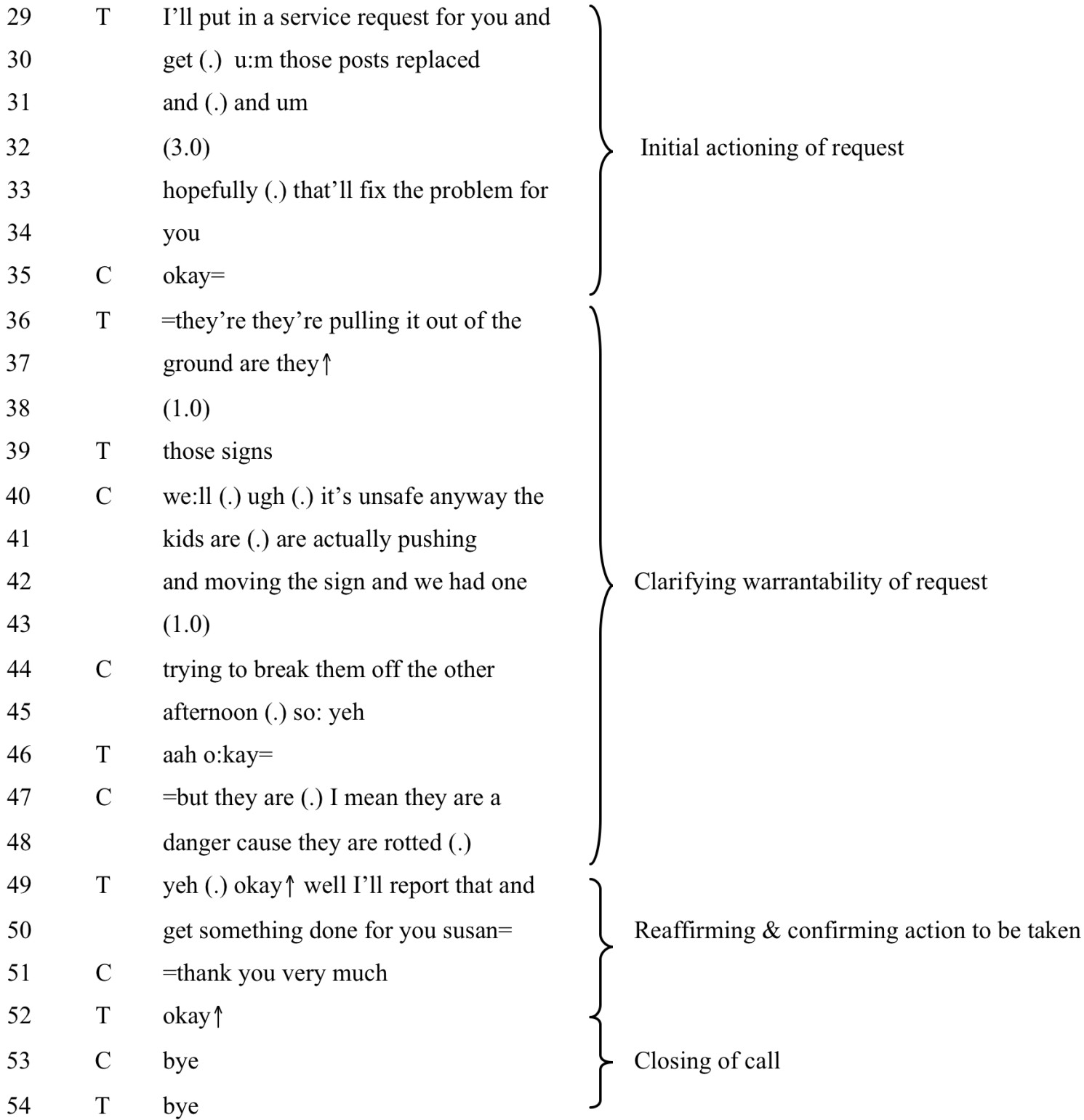


i Pseudonyms are used throughout this article.

ii

The notational symbols (Psathas, 1995, pp. 70-85) used for transcribing the telephone complaint and their meaning are shown below:

[ ] simultaneous utterance

$=\quad$ latching of utterances

(1.0) timed intervals in seconds between and within utterances

(.) untimed intervals within utterances of less than a second

(( )) description

XYZ loud delivery

soft delivery

: $\quad$ sound stretch

underlining stressed phonemes or words

$\downarrow \uparrow \quad$ intonational markers

iii Recent data (March 2008) (National Centre for Vocational Education Research September quarter 2009) show there were 15,400 administrative trainees registered in Australia.

iv In the current Business services framework 